\title{
Implementasi multiple representation pada rangkaian listrik DC sebagai upaya meningkatkan problem solving skills
}

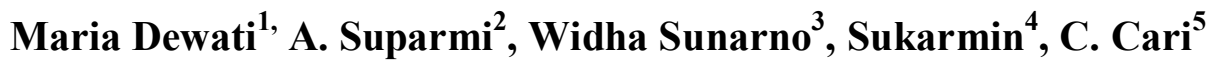 \\ ${ }^{1,3,4}$ Science Education, Doctorate Program, Universitas Sebelas Maret, INDONESIA \\ ${ }^{2,5}$ Physics Department, Universitas Sebelas Maret, INDONESIA \\ E-mail: ${ }^{1}$ merr d@student.uns.ac.id
}

\begin{abstract}
The low understanding of physics concepts, especially in DC electrical circuits which are considered abstract material, causes students difficulty in solving various problems in learning. Various attempts were made, one of which used a representation approach. This literature review article aims to observe the implementation of multiple representations (MR) in physics learning, which is considered capable of improving problem-solving skills in learning. The results showed that students who used MR a lot in each of their learning processes found it easier to understand physics concepts and were able to solve problems than students who did not use MR in their learning process. So that MR is considered as a physics learning approach tool that is able to improve students' problem-solving skills.
\end{abstract}

Keywords: Multiple representation, problem solving skills, DC electrical circuits

Abstrak: Rendahnya pemahaman konsep fisika terutama pada rangkaian listrik DC yang dianggap materi yang bersifat abstrak, menyebabkan siswa kesulitan dalam menyelesaikan berbagai masalah dalam belajar. Berbagai upaya dilakukan, salah satunya dengan menggunakan pendekatan representasi. Artikel literature review ini bertujuan untuk menyoroti implementasi multiple representation (MR) pada pembelajaran fisika, yang dianggap mampu meningkatkan keterampilan pemecahan masalah dalam belajar. Hasil penelitian menunjukkan bahwa siswa yang banyak menggunakan MR dalam setiap proses belajarnya, ternyata lebih mudah memahami konsep fisika dan mampu memecahkan masalah daripada siswa yang tidak menggunakan MR dalam belajarnya. Sehingga MR dianggap sebagai alat pendekatan pembelajaran fisika yang mampu meningkatkan problem solving skills siswa.

Kata Kunci: multiple representation, problem solving skills, rangkaian listrik DC

\section{PENDAHULUAN}

Kesulitan tertinggi dalam belajar fisika yang sering dialami oleh para siswa di universitas adalah bagaimana mereka mampu memecahkan masalah-masalah yang berhubungan dengan konsep, prinsip, prosedur demontrasi. Kebanyakan penyebab utama kesulitan siswa dalam pemecahan masalah adalah siswa yang memiliki pemahaman yang lemah tentang konsep dan hukum fisika, sehingga sering terjadi kesalah pahaman konsep. Sehingga diperlukan suatu usaha untuk membantu siswa menjadi pemecah masalah yang baik(Larkin \& Reif, 2007).

Pemecahan masalah merupakan salah satu aspek dari tujuan pembelajaran Fisika di universitas (Sutopo \& Waldrip, 2014; Yuliati, 2018). Salah satu tujuan pembelajaran Fisika adalah siswa mampu mengembangkan penalaran ilmiah. Berkembangnya penalaran ilmiah siswa jika keterampilan pemecahan masalah mampu memberikan efek dalam meningkatkan pengetahuan emosinal, kognitif dan psikomotorik siswa (Alshamali \& Daher, 2016; Riantoni, Yuliati, \& Mufti, 2017). Karena pada dasarnya pemecahan masalah itu merupakan rangkaian kognitif, perilaku dan sikap yang komplek (Josep et al., 2007; Mayer R. E., 2002).

Dijelaskan pada ranah psikologi kognitif bahwa pemecahan masalah memiliki identitas ganda sebagai fungsi kognitif dasar dan sebagai dasar dari segala aktivitas dalam mencapai 
tujuan pendidikan. Dengan kata lain bahwa semua aktivitas yang dilakukan dalam mencapai tujuan pendidikan melibatkan semua fungsi kognitif dasar manusia (Josep et al., 2007). Apabila fungsi kognitif dasar di optimalkan maka siswa akan mudah mengembangkan keterampilan pemecahan masalah, dalam mengembangkan keterampilan pemecahan masalah siswa perlu mengembangkan kerangka kerja pemecahan masalah dengan baik, dengan demikian pengetahuan konseptual fisika siswapun akan berkembang dengan baik (Riantoni et al., 2017).

Saat mengembangkan keterampilan pemecahan masalah, siswa akan membuat model pendekatan dalam pikiran mereka, bagaimana menyelesaikan masalah itu, dan model pendekatan itu diharapkan mampu membantunya dalam memecahkan masalah (Khasanah \& Yuliati, 2016; Riantoni et al., 2017). Pendekatan yang digunakan oleh siswa ada bermacammacam, seperti pendekatan yang bersifat ekplisit dan konvensional, siswa yang menggunakan pendekatan ekplisit lebih focus menyelesaikan masalah itu, menggambarkan konsep fisika yang akan diterapkan, merencanakan solusi, menyelesaikan rencana dan mengevaluasi solusi yang didapat, semua dilakukan dengan jelas, sementara pendekatan konvensional siswa mulai dengan menggambarkan sketsa, mendefinisikan yang diketahuinya, dan variabel yang tidak diketahui, memilih persamaan dan mengoreksi jawabannya (Docktor et al., 2016; Riantoni et al., 2017), ada juga siswa yang melakukan pendekatan dengan empat cara yaitu pendekatan ilmiah, plug dan chug ( cara terstruktur dan tidak terstruktur), pendekatan berbasis memori dan pendekatan tidak jelas (Riantoni et al., 2017). Pendekatan selanjutnya adalah pendekatan dengan menggunakan representasi.

Saat representasi digunakan dalam suatu masalah, ia akan membantu memfasilitasi penyelesaian masalah, terkadang representasi digunakan secara berulang-ulang untuk mendapatkan solusi yang diharapkan dalam tugas belajar (Rosengrant et al., 2017). Siswa yang menggunakan representasi secara terus menerus dalam pembelajarannya, maka akan mudah memecahkan masalah dan pembelajaran menjadi bermakna. Pada saat itu akan terbangun pemhaman konsepnya, pemahaman konseptual yang baik menyiratkan representasi pemahaman yang baik pula (Ainsworth, S. ,2006; Kohl, Rosengrant, \& Finkelstein, 2007; Rosengrant et al., 2017). Pendekatan dengan menggunakan representasi terkait dengan proses matematika, penerapan konsep, hubungan fisik, hubungan verbal, dan representasi secara grafik dan diagram, dapat digunakan siswa untuk memecahkan masalah (Kohl et al., 2007; Yuliati, 2018). Dalam menyelesaikan masalah siswa perlu memahami masalahnya lebih dahulu sehingga representasi yang akan digunakan sesuai dan mampu menemukan penyelesaian masalah dengan benar.

Pendekatan pemecahan masalah dengan berbagai cara yang digunakan siswa memiliki hubungan dengan pengalaman, persepsi dan pemahaman tentang fenomena tertentu (Yuliati, 2018). Keberhasilan siswa dalam memecahkan masalah Fisika sangat dipengaruhi oleh pendekatan pemecahan masalah yang digunakannya, dan mempengaruhi secara signifikan terhadap apa yang sudah siswa pelajari (Brown, Mason, \& Singh, 2016; Riantoni et al., 2017). Pemilihan materi dalam penelitian kali ini adalah pemecahan masalah terkait dengan konsep rangkaian listrik DC, hal ini disebabkan jarang adanya pemecahan masalah sehubungan dengan rangkaian listrik arus searah (DC). Pada rangkaian listrik arus searah (DC) konsepkonsep materi seperti hukum Ohm, hukum Kirchhoff, hubungan arus, tegangan dan resistance dalam suatu rangkaian seri maupun parallel merupakan konsep utama yang harus dipahami oleh siswa dalam pemecahan masalah, tetapi justru banyaknya kesalahpahaman siswa pada materi-materi tersebut, seperti siswa kesulitan dalam menggambar dan menafsirkan diagram sirkuit Engelhardt, P. V., \& Beichner, R. J. (2004). Pendekatan yang 
bisa digunakan untuk siswa dalam pemecahan masalah dalam rangkaian listrik arus searah akan dikupas disini.

Tujuan dari penulisan makalah ini menjelaskan mengapa multiple representation (MR) sebagai salah satu bentuk model pendekatan belajar dapat membantu siswa dalam meningkatkan keterampilan memecahkan masalah (problem solving skills), dengan cara meninjau literature terkait yang telah diteliti sebelumnya. Bukti dari literature penelitian menunjukkan bahwa penggunaan beberapa bentuk representasi ganda (MR) dalam proses pembelajaran fisika mampu meningkatkan pengetahuan siswa terhadap materi fisika yang sedang dipelajarinya sehingga memahami konsep materi tersebut dan mampu memecahkan masalah yang berkaitan dengan materi tersebut.

\section{Literature Review}

\subsection{Problem Solving}

Keterampilan memecahkan masalah seringkali menjadi topic utama dalam penelitian pendidikan Fisika, hal ini disebabkan keterampilan memecahkan masalah memiliki manfaat untuk jangka panjang. Salah satu manfaatmya adalah keterampilan memecahkan masalah dapat membantu siswa untuk memahami konsep Fisika dalam kondisi nyata (Permatasari, Istiyono, \& Kuswanto, 2019). Keterampilan pemecahan masalah dapat digunakan untuk mengukur prestasi belajar siswa (Docktor et al., 2016; Riantoni et al., 2017). Tetapi kenyataan keterampilan pemecahan masalah masih sulit diterapkan ke siswa, hal ini disebabkan dalam menyelesaikan masalah, siswa masih menggunakan struktur pengetahuan tertentu dan struktur pengetahuan tersebut tidak maksimal memberikan informasi yang dibutuhkan siswa dalam menyelesaikan masalah (Riantoni et al., 2017; Tuminaro \& Redish, 2007).

Dalam pengajaran Fisika seharusnya tidak hanya mengembangkan konsep tetapi membantu siswa untuk menerapkan pengetahuan yang sudah mereka miliki dalam situasi dimana siswa perlu memecahkan masalah dan seharusnya keterampilan memecahkan masalah siswa tersebut muncul secara alami melalui pengalaman siswa dalam menyelesaikan masalah Fisika (Eilam \& Poyas, 2014). Siswa perlu membangun pengetahuan baru mereka berdasarkan apa yang mereka ketahui, dan untuk membangun pengetahuan baru itu dibutuhkan beberapa elemen dasar dari aktivitas kognitif.

\subsubsection{Problem solving ditinjau dari struktur kognitif}

Berdasarkan teori asimilasi Ausebel, jika siswa secara bermakna memasukkan pengetahuan baru ke dalam struktur pengetahuan yang ada, maka struktur yang ada adalah faktor penting dari apa yang telah mereka pelajari sebelumnya (Bascones \& Novak, n.d.)

Pembelajaran bermakna menurut teori Ausebel adalah pengabungan pengetahuan baru yang tidak selaras, substantive, dan non verbatim ke dalam struktur kognitif. Struktur kognitif adalah merupakan kerangka kerja yang tersimpan. Dalam pembelajaran bermakna, pemecahan masalah merupakan kasus khusus. Untuk meningkatkan keterampilan pemecahan masalah dalam setiap sistem pengajaran perlu dirancang dengan benar, seperti mengajarkan kepada siswa bagaimana mereka mampu mengidentifikasikan konsep yang relevan dan mengenali hubungan antar konsep-konsep (Bascones \& Novak, n.d.).

Teori Piaget mengajarkan bahwa adaanya perbedaan pemikiran dari pembelajar pemula (anak-anak) dengan orang dewasa, mulai dari konseptual anak yaitu pergeseran dari sensorimotor ke pemikiran representasional, pra logis kepemikiran logis kongret awal sampai mencapai pemikiran formal orang dewasa (Bascones \& Novak, n.d.), sehingga saat siswa belum mencapai kemampuan operasional formal tidak akan dapat memahami konsep abstrak 
yang bermakna dan prinsip-prinsip ilmu pengetahuan. Dengan demikian dianggap pemecahan masalah siswa masih dianggap rendah (Bascones \& Novak, n.d.)

Model pemrosesan informasi telah digunakan untuk meneliti dasar penyelesaian masalah manusia (Heller, Reif, Heller, \& Reif, 2015), dan untuk memecahkan masalah di bidang yang lebih komplek (Heller et al., 2015; Larkin \& Reif, 2007). Teori pemrosesan informasi membantu pengajaran untuk memahami keterbatasan belajar, sehingga siswa mampu mengatasi masalah. Teori pemrosesan informasi dibagi menjadi dua bagian, yaitu long term memory (LTM) yang banyak membantu manusia untuk memilih informasi pada hal-hal penting dan hal tidak penting. Informasi tersebut dikodekan untuk disimpan atau diterjemahkan sebagai respon. Proses penyimpanan akan efektif jika adanya keterkaitan informasi baru dengan data atau sesuatu yang sudah ada di dalam LTM. Bagian kedua adalah short term memory (STM) atau biasa disebut work memory (WM) merupakan bagaian dimana informasi yang berasal dari LTM dan dari luar disatukan dalam operasi dan tranformasi mental. Perbedaan antara LTM dan STM adalah kapasitas penyimpanan memory, LTM memiliki kapasitas yang tak terbatas, sedangkan STM sangat terbatas (Josep et al., 2007). Dalam pendidikan sains struktur kognitif didefinisikan sebagai bentuk representasi hubungan antara unsur-unsur LTM, membentuk jaringan statis (Josep et al., 2007).

Jaringan statis akan membentuk pengetahuan statis seperti fakta, konsep, prinsip-prinsip yang biasa disebut pengetahuan deklaratif atau konseptual (Docktor et al., 2016; Josep et al., 2007). Pengetahuan deklaratif konseptual adalah predator yang baik dari kinerja pemecahan masalah(Friege \& Lind, 2006; Josep et al., 2007).

Ada empat jenis pengetahuan utama yang dianggap penting untuk pemecahan masalah seperti pengetahuan situasional, pengetahuan deklaratif, pengetahuan strategis, dan pengetahuan prosedural (Josep et al., 2007; Reif, Heller, Reif, \& Heller, 2009). Pengetahuan konseptual merupakan bagian dari sistem representasi pengetahuan manusia yang menunjukkan fakta, konsep, dan objek, tetapi untuk kinerja pemecahan masalah membutuhkan pengetahuan konseptual dan juga pengetahuan procedural (Rosengrant et al., 2017), tetapi menurut kinerja penyelesaian masalah pada dasarnya adalah aktivitas yang berorentasi pada proses yang dibantu oleh pengetahuan konseptual. Dengan demikian pengetahuan konseptual adalah merupakan pengetahuan yang penting dalam pemecahan masalah siswa.

\subsubsection{Problem solving ditinjau berdasarkan pemecah masalah expert (ahli) dan novis (pemula)}

Penelitian problem solving perlu dijelaskan adanya perbedaan pada pemecah masalah pemula dan ahli, hal ini bertujuan untuk mengembangkan strategis yang benar dalam memecahkan masalah yang nantinya akan dihadapi para siswa di sekolah, terutama untuk materi -materi sains. Beberapa penelitian problem solving menjelaskan beberapa perbedaan itu, antara lain keterampilan pemecahan masalah dilihat berdasarkan sikap ahli dan pemula dalam memecahkan masalah fisika. Pemecah ahli biasanya mengorganisasi pemahaman mereka tentang fisika dan memutuskan untuk memilih prinsip yang tepat untuk membantu mereka memecahkan masalah (Docktor et al., 2016; Riantoni et al., 2017). Sedangkan pemula memecahkan masalah dengan mengambil pemahaman mereka dan meutuskan untuk melakukan penyelesaian sederhana berdasarkan rumus.

Siswa tipe ahli memiliki pemahaman konseptual yang kuat, sedangkan pemula memiliki pemahaman konseptual yang rendah. Kemampuan pemahaman konsep yang rendah akan menimbulkan kemampuan menerapkan pengetahuan yang rendah pula sehingga ini akan menjadi hambatan dalam memecahkan masalah (Cheng, She, \& Huang, 2018). Siswa ahli 
mampu menganalisa masalah secara kualitatif. Menganalisa masalah secara kualitatif adalah factor kunci dalam pemecahan masalah dan seringkali siswa mengalami kesulitan untuk melakukan hal ini (Riantoni et al., 2017; Yuliati, 2018). Contoh analisis kualitatif seperti deskripsi verbal atau gambar, membuat diagram, yang berfungsi sebagai panduan untuk merencanakan dan mengevaluasi solusi (Gok, 2010; Larkin \& Reif, 2007; Nguyen \& Rebello, 2011).. Siswa tipe pemula focus pada masalah-masalah yang memiliki nilai kuantitatif, seperti masalah variable yang diketahui (Kohl et al., 2007; Yuliati, 2018). Pemecah masalah ahli ketika diberikan masalah kuantitatif maka yang akan dilakukan adalah melewati 4 fase analisis seperti; 1) analisis konseptual( berorentasi, mengeksplorasi), 2) analisis strategis (perencanaan, pemilihan), 3) analisis kuantitatif ( mengeksekusi, menentukan jawaban), 4) meta analisis ( merefleksi, memeriksa, mengevaluasi, membuat hubungan) (Gerace \& Beatty, 2005). Pemecah yang berpengalamaan (ahli) lebih berhasil memecahkan masalah yang dibutuhkan dengan menggunakan banyak representasi, sehingga memecahkan masalah lebih cepat terselesaikan (Gok, 2010; Kohl \& Finkelstein, 2008). Siswa ahli juga banyak mengintegrasikan ide untuk memecahkan masalah pada banyak representasi, sementara pemula seringkali hanya menggunakan satu representasi atau tidak dapat menghubungkan representasi yang berbeda(Gerace \& Beatty, 2005).

Dari berbagai perbedaan yang telah diutarakan oleh para ahli ada ahli yang menjelaskan adanya persamaan untuk pemecah ahli dan pemula yaitu untuk menyelesaikan masalah matematika mereka sama-sama menggunakan langkah sebagai berikut, yaitu orientasi, analisis, pembuatan rencana, implementasi, dan verifikasi (Gok, 2010; Schoenfeld \& Schoenfeld, 2018), tetapi perbedaannya terletak pada waktu yang dibutuhkan untuk menyelesaikan masalah tersebut, bagi ahli membutuhkan waktu relatif lebih banyak untuk membaca dan menganalisis masalah dan melihat kebelakang ( masalah serupa yang pernah terjadi sebelumnya atau retrieval), sedangkan untuk pemula menghabiskan banyak waktu untuk menemukan rencana penyelesaian dan menghitungnya.

Dengan meneliti berbagai perbedaan-perbedaan ini, maka para ahli mencoba mendefinisikan beberapa pola pemecahan masalah, sebagai pedoman umum untuk memenuhi standar yang jelas dalam memecahkan masalah. Beberapa pola pemecahan masalah tersebut digunakan untuk membuat pendekatan dan strategi problem solving.

\subsubsection{Pendekatan dan Strategi Problem Solving}

Berdasarkan penelitian -penelitian yang sudah dilakukan ada beberapa cara yang digunakan oleh siswa dalam mememcahkan masalah. Pendekatan pemecahan masalah adalah salah satu topik yang penting pada penelitian memecahkan masalah. Pendekatan pemecahan masalah terkait dengan berbagai cara yang digunakan oleh siswa untuk memecahkan masalah yang terkait dengan pengalaman, presepsi, dan pemahaman tentang fenomena tertentu (Riantoni et al., 2017). Pemahaman dan pengalaman siswa dapat dikaitkan pada topik yang sedang diajarkan, sehingga menjadi kemudahan bagi siswa untuk menghubungkan materi dengan masalah yang akan dipecahkan selama proses pembelajaran. Kondisi ini dapat mempengaruhi siswa dalam memilih jenis pendekatan yang akan mereka gunakan (Kohl \& Finkelstein, 2008; Nguyen \& Rebello, 2011; Riantoni et al., 2017).

Ada dua pendekatan yang digunakan oleh siswa dalam memecahkan masalah, yaitu secara eksplisit dan tradisional. Siswa yang menggunakan masalah secara eksplisit lebih fokus pada masalah yang dipecahkan dengan menggambarkan konsep pengetahuan (fisika) yang akan digunakan, merencanakan solusi, menyelesaikan rencana dan langkah akhirnya adalah mengevaluasi solusinya, sedangkan siswa dengan pemecahan tradisonal memulai langkahnya 
dengan menggamabr sketsa, mendefinisikan yang dikenal dan variabel yang tidak diketahui, memilih persamaan dan mengoreksinya (Docktor et al., 2016; Riantoni et al., 2017).

Ada pendekatan masalah yang menjelaskan bahwa siswa cenderung menyelesaikan masalah dengan menggunakan empat cara seperti, pendekatan ilmiah, plug dan chug ( cara terstruktur dan tidak terstruktur), pendekatan berbasis memori dan pendekatan yang tidak jelas (Riantoni et al., 2017).

Beberapa pendekatan pemecahan masalah yang digunakan oleh siswa dianggap mampu secara efektif membantu siswa menyelesaikan masalah, seperti yang dijelaskan oleh para ahli di atas. Pendekatan memecahkan masalah yang digunakan oleh siswa dapat mempengaruhi keberhasilan mereka dalam memecahkan masalah fisika, dan mempengaruhi secara berarti terhadap apa yang sudah siswa pelajari (Mason \& Singh, 2010; Riantoni et al., 2017).

Berdasarkan beberapa pendekatan - pendekatan yang ada dalam pemecahan masalah, maka akan diteruskan menjadi suatu strategi pemecahan masalah. Strategi pemecahan masalah merupakan teknik yang akan menjamin penyelesaian, dan berfungsi sebagai acuan dalam proses pemecahan masalah (Gick \& Gick, 2011).

Dalam pembelajaran fisika, strategi hanya berfokus pada bagaimana memecahkan masalah yang membuktikan perhitungan matematika telah menjadi penyebab kurangnya keterampilan pemecahan masalah siswa (Riantoni et al., 2017). Strategi pemecahan masalah seperti analisis tidak disadari menjadi cara terakhir saat memecahkan masalah dan strategi hanya berfungis untuk menggambarkan proses yang sedang dilakukan oleh pemecah masalah (Gick \& Gick, 2011).

Pada tabel 1, di bawah ini akan menjelaskan beberapa strategi memecahan masalah fisika dari beberapa peneliti problem solving.

Tabel 1. Strategi Problem Solving

\begin{tabular}{|c|c|c|c|}
\hline No. & Nama Peneliti & Tahun & Strategi pelaksanaan \\
\hline 1 & $\begin{array}{l}\text { Heller ( Logical } \\
\text { solving) }\end{array}$ & 1995 & $\begin{array}{l}\text { a. Fokus pada masalah } \\
\text { b. Menggambarkan konsep } \\
\text { c. Merencanakan solusi } \\
\text { d. Menjalankan rencana } \\
\text { e. Mengevaluasi jawaban }\end{array}$ \\
\hline 2 & $\begin{array}{l}\text { Bagno \& Eylor's } \\
\text { (didactic) }\end{array}$ & 1997 & $\begin{array}{l}\text { a. Memecahkan } \\
\text { b. Menggambarkan } \\
\text { c. Mengkonsep } \\
\text { d. Mengaplikasikan } \\
\text { e. Menghubungkan }\end{array}$ \\
\hline 3 & $\begin{array}{l}\text { Bolton \& Ross ( } \\
\text { computer } \\
\text { assisted problem } \\
\text { solving) }\end{array}$ & 1997 & $\begin{array}{l}\text { a. Persiapan } \\
\text { b. Kerja } \\
\text { c. Memeriksa }\end{array}$ \\
\hline 4 & $\begin{array}{l}\text { Savage \& } \\
\text { William ( } \\
\text { Physics problem } \\
\text { using real world } \\
\text { problem solving) }\end{array}$ & 1990 & $\begin{array}{l}\text { a. Menyiapkan model } \\
\text { b. Menganalisa masalah } \\
\text { c. Menafsirkan \& mengkonfirmasi } \\
\text { jawaban matematis } \\
\text { d. Menghasilkan solusi }\end{array}$ \\
\hline 5 & Reif et. al & 1995 & $\begin{array}{l}\text { a. Menganalisa masalah } \\
\text { b. Membangun solusi } \\
\text { c. Memeriksa }\end{array}$ \\
\hline
\end{tabular}




\begin{tabular}{|c|c|c|c|}
\hline No. & Nama Peneliti & Tahun & Strategi pelaksanaan \\
\hline 6 & Loucks & 2007 & $\begin{array}{l}\text { a. Mengidentifikasi tipe dari masalah } \\
\text { b. Mengurutkan berdasarkan interval } \\
\text { dan/atau objek } \\
\text { c. Menemukan persamaan yang } \\
\text { diketahui dan tidak diketahui } \\
\text { d. Menguraikan solusi atau membuat } \\
\text { tindakan reaksi } \\
\text { e. Menghitung secara matematik }\end{array}$ \\
\hline 7 & $\begin{array}{l}\text { Kowalski et.al } \\
\text { (computer } \\
\text { problem solving) }\end{array}$ & 2009 & $\begin{array}{l}\text { a. Mengidentifikasi prinsip dasar } \\
\text { b. Menyelesaikan } \\
\text { c. Memeriksa }\end{array}$ \\
\hline
\end{tabular}

Berdasarkan tinjauan literatur yang tercantum pada tabel 1 bahwa strategi memecahkan masalah fisika secara umum meliputi menganalisis (mengidentifikasi), memecahkan dan memeriksa, yang akan digunakan oleh siswa, strategi ini dapat efektif dan mampu meningkatkan kinerja belajar siswa jika siswa memahaminya dengan benar, seperti pada saat siswa menganalisis atau tahap mengidentifikasi atau memahami masalah, yang harus siswa lakukan adalah mampu memeriksa aspek kualitatif dan kuantitatif dari masalah dan menafsirkan masalah dengan mengingat pengetahuan dan pengalamannya sendiri. Pada tahap berikutnya adalah tahap memecahkan masalah dimana siswa dapat menggunakan pemahaman kualitatif masalah untuk mempersiapkan solusi kuantitatif, dan pada tahap terakhir yaitu memeriksa, siswa harus memeriksa solusi untuk menilai apakah solusi tersebut benar, memuaskan, apakah perlu direvisi dengan benar jika ada kekurangan yang terdeteksi saat memeriksa. Apabila siswa mampu melakukan ketiga tahap ini maka harapannya siswa mampu terampilan sebagai pemecah masalah.

\subsection{Multiple Representation ( Representasi ganda) dalam pembelajaran Fisika}

Tidak mudah bagi siswa belajar fisika terutama bagi siswa pada tingkatan perguruan tinggi, hal ini dikarenakan materi-materi fisika lebih banyak mengarah ke konsep dan mengaplikasikan dalam kehidupan nyata. Materi yang diajarkan oleh guru tentunya tidak hanya bersifat verbal saja, jikalau mengharapkan siswa dengan cepat dapat memahami dan mengerti konsep yang diajarkan, tetapi dengan beberapa pendekatan seperti yang direpresentasikan dalam bentuk gambar, grafik, diagram maupun matematik. Materi fisika memiliki banyak konsep, proses atau hubungan antar variabel, dapat dipahami dengan mudah ketika disajikan dalam beberapa jenis gambar, hal ini dikarenakan ternyata gambar dapat menunjukkan sekaligus menjelaskan arti kata-kata atau bentuk verbal dari suatu materi fisika (Rosengrant et al., 2017). Menggunakan pendekatan dan teknik lebih dari satu format representasi ternyata akan lebih memudahkan untuk menyampaikan informasi dan mendukung kontruksi pengetahuan. Bahkan sejumlah teori menyatakan bahwa penggunaan banyak representasi dapat meningkatkan pembelajaran.

Dalam penelitian pendidikan, representasi dapat dibedakan dalam dua jenis, yaitu representasi eksternal (seperti teks, grafik, atau gambar), dan representasi internal (model mental)yang dibuat oleh siswa sendiri terkait dengan konten pembelajaran tertentu yang sedang dijelaskan (Gilbert, J. K., 2009; Ainsworth, S., 2006; Rosengrant et al., 2017). Penggunaan representasi dalam proses pembelajaran fisika tidak hanya grafik, verbal, dan gambar tetapi juga menggunakan representasi matematik, untuk menggambarkan suatu sistem dengan seperangkat variabel dan menjelaskan hubungan antar variabel (Angell, C et al. 2008; 
Opfermann Maria et al 2016). Para peneliti menjelaskan apabila siswa memahami berbagai macam representasi, maka siswa akan terbantu dalam membangun pemahaman pengetahuan sains mereka dengan sempurna (Ainsworth, S., Prain, V., \& Tytler, R. 2011; Rosengrant et al., 2017). Kemampuan siswa untuk merepresentasikan semua konsep yang sama dalam format yang berbeda-beda termasuk verbal, visual, mathematic, graphic di sebut multiple representation ability (Ainsworth et.al, 2011).

Mengintergrasikan banyak representasi dapat menghasilkan lingkungan belajar yang konseptual yang baik buat siswa (Dori, Y. J., \& Belcher, J., 2005; Gilbert, J. K., 2009; Rosengrant et al., 2017). Tetapi tidak semua siswa mendapat manfaat penuh dari mengintergrasikan representasi ganda dalam proses pembelajaran sains mereka. Sebagian besar siswa kesulitan dalam menafsirkan, menghubungkan, dan menerterjemahkan berbagai representasi untuk mengembangkan dan mengkomunikasikan ide-ide mereka (Kozma, 2003; Rosengrant et al., 2017). Siswa memiliki kecenderungan menggunakan hanya satu representasi dan ironisnya mereka berhasil membentuk penjelasan dengan satu representasi, tetapi mereka bisa keliru saat mengintergrasikan banyak representasi (Schijf, H. J. M., \& Simon, H. A., 1998). Menafsirkan dan memproduksi representasi menuntut pemahaman bentuk dan konten representasi yang effisien, mengolah pesan dalam bentuk representasi tidak dengan otomatis atau mudah tetapi membutuhkan sebuah keterampilan. Setiap siswa memiliki proses yang berbeda dalam menerjemaahkan rangkaian representasi yang mungkin sama, berbagai cara yang berbeda yang mereka lakukan tergantung pada pengetahuan konsep mereka (Cook, M. et. al, 2011). Bagi pengajar harus mampu membatu siswa dalam menemukan cara yang efektif untuk mengintergrasikan representasi ganda untuk membantu proses pembelajaran siswa (Ainsworth, S., 2006; Rosengrant et al., 2017).

Salah satu bentuk kerangka kerja yang dianggap mampu membantu guru sains untuk memahami siswa dalam menggunakan banyak representasi adalah kerangka kerja Ainsworth (Ainsworth, S., 2006). Kerangka kerja dapat digunakan untuk menganalisis berbagai strategi yang digunakan siswa ketika belajar dari berbagai bentuk representasi, kerangka kerja Ainsworth memiliki tiga fungsi yang berbeda dari representasi ganda untuk pembelajaran, yaitu saling melengkapi, membatasi, dan membangun. Masing-masing dari fungsi representasi ganda akan saling terhubung dengan strategi siswa, sehingga memiliki pemahaman sebagai berikut, 1) mampu melengkapi representasi lain, 2) untuk membatasi interprestasi, 3) untuk membangun pemahaman yang lebih dalam. Dengan memahami dan mengkomunikasikan berbagai representasi ini diharapkan siswa mampu menggunakan berbagai bentuk representasi ganda dalam proses pembelajaran sains.

\subsection{Pemanfaatan Multiple representation ( representasi ganda) untuk meningkatkan Problem solving}

Salah satu tujuan dari pengajaran fisika adalah untuk membuat siswa kita mampu menyelesaikan masalah-masalah fisika secara benar. Hal ini menuntut siswa untuk memahami berbagai cara ataupun teknik, salah satunya dengan menggunakan banyak representasi untuk membantu mereka dalam memecahkan masalah fisika. Ketika siswa mampu memecahkan masalah fisika, maka dianggap siswa tersebut memahami konsep fisika. (Gerace, W. J. et.al, 2001) menyatakan bahwa keterampilan memecahkan masalah dianggap sebagai tolak ukur penguasaan konsep fisika.

Pada saat seseorang membaca dan menganalisis masalah, seseorang akan membentuk representasi masalah dengan menafsirkan dan mengasosiasikannya dalam bentuk pengetahuan (tentang konsep, prinsip fisika, persamaan, prosedur, gambar terkait dan masalah terkait). Pembentukan representasi masalah berlangsung secara alami, ketika seseorang berusaha 
untuk memahami dan memecahkan masalah (Rosengrant et al., 2017), dengan demikian siswa yang menguasai konsep fisika harus mampu mengelola pengetahuan konseptual dan representasi mereka untuk menyelesaikan masalah fisika. Siswa mampu melakukan pemecahan masalah dengan menggunakan representasi dari konsep terkait selama proses pembelajaran dengan representasi ganda. Hal ini didukung pernyataan (Cook, M. et. al, 2011), bahwa siswa yang belajar fisika di lingkungan yang selalu menggunakan representasi ganda cenderung membangun beberapa representasi untuk menyelesaikan masalahnya. Membangun representasi baru untuk memecahkan masalah adalah usaha yang kreatip.

Siswa diberikan tugas, untuk memecahkan suatu masalah dalam proses belajar di sekolah, pada saat itu siswa melakukan proses berpikir. Proses berpikir tersebut dianggap sebagai menjalankan tugas-tugas kognitif siswa atau biasa disebut beban memori kerja (beban kognitif). Jika beban kognitif ini terlalu berat maka akan terjadi kecenderungan melupakan, oleh karena itu untuk menghindari hal tersebut sebaiknya beban kognitif harus pada tahap yang wajar pada saat proses belajar atau proses menyelesaikan masalah (Heller et al., 2015). Bagaimana cara untuk mengurangi beban kognitif siswa? Salah satu cara yang direkomendasi oleh para ahli adalah dengan menghadirkan representasi ekternal (seperti representasi ganda) dalam proses belajar siswa, seperti diagram, gambar, tabel (Ainsworth, S., 2006).

Bagaimana keterkaitan antara pemecah masalah ahli dalam menggunakan representasi?, menurut studi dalam kognitif sains bahwa pemecah masalah ahli sering menggunakan representasi kualitatif seperti gambar, grafik, diagram, untuk membantu mereka memahami masalah sebelum mereka menggunakan persamaan untuk menyelesaikannya secara kuantitatif (Heuvelen, Zou, Heuvelen, \& Zou, 2001), representasi kualitatif mampu menfasilitasi pemahaman tentang tugas dan masalah sehingga masalah dapat diselesaikan dengan benar. Sehingga penting bagi siswa untuk mengetahui dan memahami penggunaan representasi untuk memahami masalah sebelum menemukan solusi. Solusi yang di dapat oleh siswa harus mengikuti langkah-langkah spesifik sebagai berikut, 1) siswa harus memahami masalahnya, siswa harus memperhatikan apa masalahnya dan apa yang diperlukan dalam masalahnya, 2) siswa harus membuat rencana yang menunjukkan bagaimana menghubungkan yang tidak diketahui dari variabel yang dikenal, mengidentifikasi variabel, sepertinya menggunakan symbol dapat membantu saat membuat rencana, 3) siswa harus menyelesaikan rencana, menerapkan persamaan, 4) siswa harus mengevaluasi solusi ( meninjau apakah solusi lengkap dan rasional) (Tms \& Sirait, 2017).

Representasi ganda dikatakan mampu menjadi alat bantu dalam proses pembelajaran, hal ini karena representasi ganda mampu menvisualisasikan berbagai konsep dan menjembatani ke dalam berbagai persamaan yang benar untuk menyelesaikan masalah. Sebagai contoh beberapa siswa yang mempresentasikan masalah dengan menggambar, atau membuat diagram memiliki ketepatan penyelesaian masalah yang besar daripada siswa yang tidak melakukannya (Mason \& Singh, 2010; Tms \& Sirait, 2017). Berdasarkan beberapa juga menjelaskan bahwa hasil belajar dapat meningkat dengan menggunakan representasi ganda, dengan menggunakan strategi pembelajaran yang diadaptasi dari Ainsworth ((Eilam \& Poyas, 2014). Seorang siswa meningkatkan peluang mereka untuk memecahkan masalah dengan benar jika mereka memasukkan representasi diagram matematis sebagai bagaian proses penyelesaian masalah (Kohl et al., 2007; Rosengrant, Heuvelen, \& Etkina, 2006). Penggunaan representasi ganda di terima secara luas sebagai pendekatan pengajaran yang efektif yang meningkatkan pemahaman siswa tentang konsep atau operasi tertentu (Rosengrant et al., 2006). Masalah yang melibatkan representasi ganda dapat meningkatkan kemampuan siswa untuk memecahkan masalah yang sama dalam representasi lain dan meningkatkan kompetensi 
siswa dalam pembelajaran (Nguyen \& Rebello, 2011). Tetapi ada sebagian besar siswa yang merasa kesulitan untuk mengubah antar representasi dan mengekploitasi kelebihan yang dimiliki oleh representasi ganda (Ainsworth, S., 2006; Wagner, J. F. et.al, 2012).

\section{Kesimpulan}

Representasi ganda dapat digunakan sebagai alat bantu dalam proses pembelajaran untuk membantu siswa meningkatkan pemecahan masalah, terutama dalam pengajaran fisika, dapat membantu siswa untuk memahami konsep dan menvisualisasikan masalah sebelum menuju ke persamaan matematika. Salah satu kerangka kerja yang dapat digunakan untuk membantu mengembangkan fungsi dari representasi ganda dalam rangka meningkatkan pemahaman pengetahuan dan penyelesaian masalah adalah kerangka kerja analisis yang dikembangkan oleh Ainsworth, dan pengajar harus memahami betul strategi-strategi yang ada di dalam ini, sehingga diharapkan guru mengetahui apa yang harus di lakukannya dalam membantu siswa dalam proses pembelajaran.

Pengajar atau guru juga harus mempertimbangkan kompleksitas pembelajaran, saat menggunakan representasi ganda, pengajar perlu memeriksa informasi apa yang sebenarnya dapat diakses oleh siswa dan bagaimana mereka dapat menggunakan informasi tersebut dan kemudian menemukan cara yang lebih efektif untuk mengintergrasi representasi ganda dalam membantu proses pembelajaran siswa (Ainsworth, S., 2006). Usaha meningkatkan problem solving siswa harus ada kerjasama antara guru dan siswa, siswa tidak mungkin di lepaskan tanpa didorong dan dibimbing oleh pengajar dalam menggunakan representasi ganda untuk memecahkan masalah. Dengan demikian tujuan pembelajaran sains menjadi lebih konstruktif akan tercapai.

\section{DAFTAR PUSTAKA}

Ainsworth, S. (2006). DeFT: A conceptual framework for considering learning with multiple representations. Learning and instruction, 16(3), 183-198.

Ainsworth, S., Prain, V., \& Tytler, R. (2011). Drawing to learn in science. Science, 33(6046), 1096-1097

Alshamali, M. A., \& Daher, W. M. (2016). Scientific Reasoning and Its Relationship with Problem Solving: the Case of Upper Primary Science Teachers. International Journal of Science and Mathematics Education, 1003-1019. https://doi.org/10.1007/s10763-015-9646-1

Angell, C., Kind, P. M., Henriksen, E. K., \& Guttersrud, Ø. (2008). An empiricalmathematical modelling approach to upper secondary physics. Physics Education, 43(3), 256.

Bascones, J., \& Novak, J. D. (n.d.). European Journal of Science Alternative instructional systems and the development of problem - solving skills in physics Alternative instructional systems and the development of problem-solving skills in physics, (June 2013), 37-41.

Brown, B. R., Mason, A., \& Singh, C. (2016). Improving performance in quantum mechanics with explicit incentives to correct mistakes, 010121, 1-20. https://doi.org/10.1103/PhysRevPhysEducRes.12.010121

Cheng, S., She, H., \& Huang, L. (2018). The Impact of Problem-Solving Instruction on Middle School Students ' Physical Science Learning: Interplays of Knowledge , Reasoning , and Problem Solving, 14(3), 731-743. https://doi.org/10.12973/ejmste/80902

Cook, M., Wiebe, E., \& Carter, G. (2011). Comparing visual representations of DNA in two 
multimedia presentations. Journal of Educational Multimedia and Hypermedia, 20(1), 21-42

Docktor, J. L., Dornfeld, J., Frodermann, E., Heller, K., Hsu, L., Jackson, K. A., ... Yang, J. (2016). Assessing student written problem solutions: A problem-solving rubric with application to introductory physics, 010130, 1-18. https://doi.org/10.1103/PhysRevPhysEducRes.12.010130

Dori, Y. J., \& Belcher, J. (2005). How does technology-enabled active learning affect undergraduate students' understanding of electromagnetism concepts?. The journal of the learning sciences, 14(2), 243-279.

Eilam, B., \& Poyas, Y. (2014). External Visual Representations in Science Learning: The case of relations among system components External Visual Representations in Science Learning: The case of relations, (December), 37-41. https://doi.org/10.1080/09500690903503096

Engelhardt, P. V., \& Beichner, R. J. (2004). Students' understanding of direct current resistive electrical circuits. American Journal of Physics, 72(1), 98-115.

Friege, G., \& Lind, G. (2006). Types and qualities of knowledge and their relations to problem solving in physics, 437-465.

Gerace, W. J., Dufresne, R. J., Leonard, W. J., \& Mestre, J. P. (2001, July). Problem solving and conceptual understanding. In Proceedings of the 2001 Physics education research conference (p. 33). Physics Education Research Conference, Annual Conference

Gerace, W. J., \& Beatty, I. D. (2005). Teaching vs . Learning: Changing Perspectives on Problem Solving in Physics Instruction, 1-10.

Gick, M. L., \& Gick, M. L. (2011). Problem-Solving Strategies Problem-Solving Strategies, (June 2012), 37-41.

Gilbert, J. K. (2009). Multiple representations in chemical education (Vol. 4). D. Treagust (Ed.). Dordrecht: Springer.

Gok, T. (2010). The General Assessment of Problem Solving Processes and Metacognition in Physics Education, 2(2), 110-122.

Heller, J. I., Reif, F., Heller, J. I., \& Reif, F. (2015). Prescribing Effective Human ProblemSolving Processes: Problem Description in Physics Prescribing Effective Human Problem- Solving Processes: Problem Description in Physics, 0008(October). https://doi.org/10.1207/s1532690xci0102

Heuvelen, A. Van, Zou, X., Heuvelen, A. Van, \& Zou, X. (2001). Multiple representations of work - energy processes Multiple representations of work - energy processes, 184. https://doi.org/10.1119/1.1286662

Josep, J., Benaguasil, S. I. E. S., Tomás, C., De, V., Sanjosé, V., Science, L., \& València, U. De. (2007). Cognitive variables in science problem solving: A review of research, 25-32.

Khasanah, N., \& Yuliati, L. (2016). Jurnal Pendidikan IPA Indonesia PROBLEMS IN DYNAMICS OF ROTATIONAL MOTION TOPIC, 5(2), 186-191. https://doi.org/10.15294/jpii.v5i2.5921

Kohl, P. B., \& Finkelstein, N. D. (2008). Patterns of multipe representation use by experts and novices during physics problem solving. Physical Review Special Topics - Physics Education Research, 4(1), 1-13. https://doi.org/10.1103/PhysRevSTPER.4.010111

Kohl, P. B., Rosengrant, D., \& Finkelstein, N. D. (2007). Strongly and weakly directed approaches to teaching multiple representation use in physics. Physical Review Special Topics - Physics Education Research, 3(1), 1-10. https://doi.org/10.1103/PhysRevSTPER.3.010108 
Kozma, R. (2003). The material features of multiple representations and their cognitive and social affordances for science understanding. Learning and Instruction, 13(2), 205226.

Larkin, J. H., \& Reif, F. (2007). European Journal of Science Education Understanding and Teaching Problem - Solving in Physics Understanding and Teaching ProblemSolving in Physics, (April 2013), 37-41.

Mason, A., \& Singh, C. (2010). Surveying graduate students' attitudes and approaches to problem solving, (December), 1-16. https://doi.org/10.1103/PhysRevSTPER.6.020124

Mayer R. E. (2002). Rote Versus Meaningful Learning. Theory Into Practice, 41(4), 226-233. Retrieved from http://eds.a.ebscohost.com/eds/pdfviewer/pdfviewer?vid=70\&sid=c4c835f7-94314b9e-b980-430b230d5df4\%40sessionmgr4006

Nguyen, D., \& Rebello, N. S. (2011). Students' Difficulties With Multiple Representations in Introductory Mechanics *, 8(5), 559-569.

Permatasari, A. K., Istiyono, E., \& Kuswanto, H. (2019). Developing Assessment Instrument to Measure Physics Problem Solving Skills for Mirror Topic, 358-366.

Reif, F., Heller, J. I., Reif, F., \& Heller, J. I. (2009). Knowledge structure and problem solving in physics Knowledge Structure and Problem Solving in Physics, (April 2013), 3741.

Riantoni, C., Yuliati, L., \& Mufti, N. (2017). Jurnal Pendidikan IPA Indonesia POWER ON STUDENTS AS PHYSICS TEACHER CANDIDATES, 6(1), 55-62. https://doi.org/10.15294/jpii.v6i1.8293

Rosengrant, D., Heuvelen, A. Van, \& Etkina, E. (2006). Case Study: Students ' Use of Multiple Representations in Problem Solving *, 49-53.

Rosengrant, D., Heuvelen, A. Van, Etkina, E., Planinic, M., Susac, A., Ivanjek, L., ... Lee, Y. (2017). Case Study: Students ' Use of Multiple Representations in Problem Solving *, 132(August), 49-53. https://doi.org/10.1063/1.2820914

Schoenfeld, A. H., \& Schoenfeld, A. H. (2018). Teaching Problem-Solving Skills, 9890(1980). https://doi.org/10.1080/00029890.1980.11995155

Schijf, H. J. M., \& Simon, H. A. (1998). One person: multiple representations: an analysis of a simple, realistic multiple representation learning task. Learning with multiple representations, 197-236

Sutopo, \& Waldrip, B. (2014). Impact of a Representational Approach on Students '. International Journal of Science and Mathematics Education, 12(November 2012), 741-766.

Tms, H., \& Sirait, J. (2017). Representations Based Physics Instruction to Enhance Students ' Problem Solving, (January 2016). https://doi.org/10.12691/education-4-1-1

Tuminaro, J., \& Redish, E. F. (2007). Elements of a cognitive model of physics problem solving: $\quad$ Epistemic games, (January), 1-22. https://doi.org/10.1103/PhysRevSTPER.3.020101

Wagner, J. F., Manogue, C. A., \& Thompson, J. R. (2012, February). Representation issues: Using mathematics in upper-division physics. In AIP Conference Proceedings (Vol. 1413, No. 1, pp. 89-92). AIP.

Yuliati, L. (2018). Problem Solving Skills on Direct Current Electricity through InquiryBased Learning with PhET Simulations, 11(4), 123-138. 